\title{
DEVELOPMENT OF AN ASSESSMENT METHODOLOGY FOR GEOPRESSURED ZONES OF THE UPPER GULF COAST BASED ON A STUDY OF ABNORMALLY PRESSURED GAS FIELDS IN SOUTH TEXAS
}

\author{
Progress Report \\ for Period 1 December 1975-29 February 1976
}

R. K. Swanson, P. Oetking, J. S. Osoba, R. C. Hagens

Southwest Research Institute

8500 Culebra Road

San Antonio, Texas 78284

Prepared for

THE U. S. ENERGY RESEARCH AND DEVELOPMENT ADMINISTRATION UNDER CONTRACT NO. E(11-1)-2687

February 1976

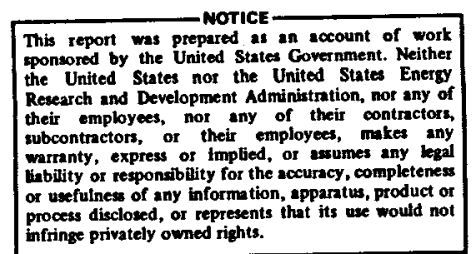

Approved:
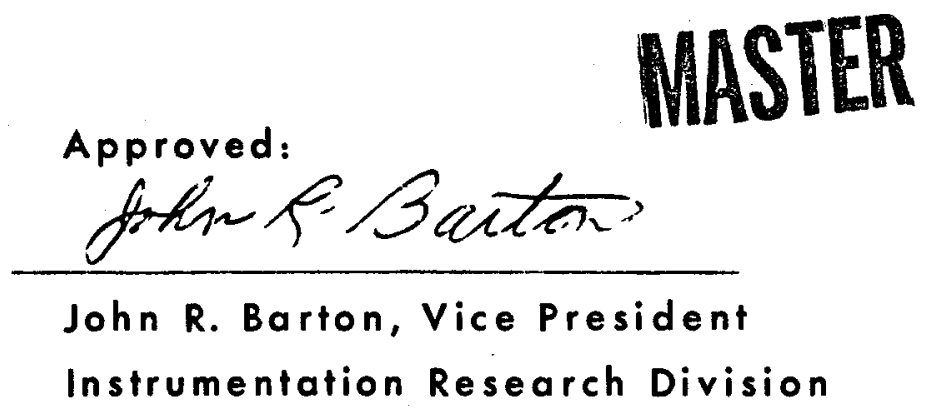

Distribution OF THIS DOCUMENT IS UNLIMITED fle 


\section{DISCLAIMER}

This report was prepared as an account of work sponsored by an agency of the United States Government. Neither the United States Government nor any agency Thereof, nor any of their employees, makes any warranty, express or implied, or assumes any legal liability or responsibility for the accuracy, completeness, or usefulness of any information, apparatus, product, or process disclosed, or represents that its use would not infringe privately owned rights. Reference herein to any specific commercial product, process, or service by trade name, trademark, manufacturer, or otherwise does not necessarily constitute or imply its endorsement, recommendation, or favoring by the United States Government or any agency thereof. The views and opinions of authors expressed herein do not necessarily state or reflect those of the United States Government or any agency thereof. 


\section{DISCLAIMER}

Portions of this document may be illegible in electronic image products. Images are produced from the best available original document. 


\section{INTRODUCTION}

This is a report of the progress during the third quarter of detailed $s$ tudy of abnormally pressured gas fields in South Texas, under ERDA Contract No. E(11-1)-2687. The purpose of this study is the development of an assessment methodology, transferrable to other regions, by which the potential of geopressured hot-water reservoirs as energy sources may be evaluated.

The material part of this progress report, is contained in a paper prepared by project personnel for presentation at the Second Geopressured Geothermal Energy Conference in Austin, Texas on February 23, 24 and 25, 1976. A copy of the paper is attached to this report.

\section{PROJECT ACCOMPLISHMENTS}

During the third quarter, investigation of records of the producing fields in the study area was completed. All geopressured producing fields have been identified. There are twenty-four separate gas fields, twenty of which are in Hidalgo, three in the lower half of Kenedy, and one in Cameron County. No geopressured production was identified in Willacy County.

The detailed study of producing fields in the area has continued. Representative values of temperature, pressure, and effective permeability have been established ior all the fields. McAllen-Pharr field was investigated in detail, and the results combined with earlier results of a study of the South Edinburg Field. Strong correlation of thick sandstones of the Marks and Bond series (Frio-Vicksburg) between these fields is very impressive. The probability of large continuous regional aquifers in this zone is high.

The McAllen Ranch Field, along the Vicksburg trend in western Hidalgo County was also given detailed study. Here, large continuous aquifers could not be identified, although overall sand deposition is extensive. Comprehensive core data of sands from 10,600 to 12,600 feet from a typical field well were provided by Shell Oil Co. and the results were correlated with calculated permeability values from buildup-drawdown tests in the same well. These data indicate average permeability values substantially less than 1.0 md.

Effective permeability values from four-point test results, and from absolute open-flow potential tests, were calculated for all 24 fields in the study area. Values ranged from 8.0 md maximum (Stillman field, Kenedy Co.) to less than $0.1 \mathrm{md}$, with average values less than $1.0 \mathrm{md}$. It is evident that permeability is the critical reservoir parameter in South Texas. 
In the McAllen-Pharr field study, producing reservoirs were found to occur from 5,800 feet to nearly 14,000 feet, with the top of geopressure near 8,500 feet. Effective permeabilities from a large number of these reservoirs were obtained and the effect of depth on permeability determined. It was found that permeability in every case is an inverse function of depth in that field, ranging from 16 md above the geopressured zone to less than $.03 \mathrm{md}$ at 14,000 feet. The reduction in permeability with depth is approximately one order of magnitude for each 2, 000 feet of depth, over the entire range of producing depths.

Temperature data were obtained from well logs, and corrected to equilibrium values. Representative values of depth of a $300^{\circ} \mathrm{F}$ isogeothermal surface were calculated for each field in the study. These values range from 10,500 feet to 13,500 feet in Hidalgo County, increasing to 15,000 feet near the depo-center in Central Cameron County.

A detailed map of the $300^{\circ} \mathrm{F}$ geotherm was plotted over the McAllenPharr-Edinburg area, and generally showed deepening of the geotherm over the four major field structures. The complexity of the temperature data no doubt reflects the complex fault patterns in the area.

These and other aspects of the study are more fully discussed in the enclosed paper.

\section{WORK TO BE ACCOMPLISHED}

In the remaining period of the study, two fields of considerable interest $w i l l$ be investigated in detail. These are the Weslaco-Mercedes fields, in southeastern Hidalgo County, and the fields on the upper McAllen Fault trend, where the highest permeabilities in the region were located. . The latter include Hargill, LaJara, Cerda, Stillman and Tordilla fields.

Attempts will be made to obtain additional connate water data. So far, data have been obtained from Jeffress, S. Edinburg, McAllen and S. Weslaco fields.

Test data on a well in the S. Weslaco area, abandoned early in 1975, have been located. This well is apparently a geopressured water producer, on which completion as a gas well was attempted. We will attempt to analyze data from this test, and discuss the implications of the well as a geothermal producer.

Good progress has been made on the project, and significant results shown. There are no anticipated problems in completing the program on schedule within the available funding. 
SOUTH TEXAS

\author{
by \\ J. S. Osoba \\ Professor, Petroleum Engineering \\ Texas A \& M University \\ R. K. Swanson \\ P. Oetking \\ Southwest Research Institute \\ R. C. Hagens \\ Corpus Christi, Texas
}

For presentation at

Second Geopressured-Geothermal Energy Conference

Austin, Texas

23-25 February 1976 


\begin{abstract}
Twenty-four separate gas fields producing from geopressured sands have been identified in the South Texas area that includes Hidalgo, Cameron, Willacy and the lower half of Kenedy Counties. Of these, twenty are in Hidalgo County. Geological study and detailed investigation of reservoir parameters in each of the fields have been accomplished. Two areas in particular are discussed in some detail in this paper: the Vicksburg Trend on the west, represented by McAllen Ranch Field, and the south central Frio-Vicksburg delta, including the McAllenPharr-Edinburg area.

The depth of the geopressured zone in the study area ranges from 7,000 feet in western Hidalgo County to 12,000 feet in central Cameron County.

Temperature data within the fields, corrected to equilibrium values, yields a $300^{\circ} \mathrm{F}$ isogeothermal surface at depths of 10,500 feet to 14,000 feet over the study area.

The most critical reservoir parameter was found to be the effective permeability in all the fields in the region. Permeability values ranged from $0.03 \mathrm{md}$ to $8.0 \mathrm{md}$, with average values over all the fields near $1.0 \mathrm{md}$. A permeability profile of McAllen-Pharr shows permeability there to be an inverse function of depth, with effective permeability values from $16 \mathrm{md}$ above the geopressured zone to $0.03 \mathrm{md}$ at 14,000 feet. The permeability reduction amounts to approximately one order of magnitude for each 2,000 feet of depth.
\end{abstract}




\section{INTRODUCTION}

Extraction of useful thermal energy from the earth is both theoretically possible and, in some cases, a practical accomplishment. A positive temperature gradient exists over all the earth's surface, but at the present time, only the occurrence of anomalous conditions permits exploitation of the available heat in useful quantities. In general, these conditions include abnormal temperature gradients, unusual reservoir conditions, and natural production of dry steam.

There is considerable hope for the development of much more generally occurring systems which produce hot water only, and in at least one such reservoir, the Imperial Valley of California, this goal may be near accomplishment. Less well known, but potentially of great importance, are the abnormally pressured sediments of the Gulf Coast. Here, moderately high temperatures are available at reasonable depths and encompass a great number of sandstone aquifers under abnormally high pressure. The areal extent of this system may be great enough so that even though the enthalpy is relatively low, the large total volume and high formation pressure, capable of providing lift to the surface without pumping, make these reservoirs among the most interesting of all the liquid-dominated geothermal systems. In addition, there is considerable evidence that the water contains near-saturation quantities of dissolved methane which could directly supplement the nation's natural gas reserves. This potential energy source is referred to as the "geopressure-geothermal resource".

For production of useful energy from this resource to become a reality, several conditions must be coincident. First, aquifers of considerable thickness at temperatures of at least $150^{\circ} \mathrm{C}\left(300^{\circ} \mathrm{F}\right)$ must be located; second, these aquifers must be contiguous over areas measured in terms of several to many square kilometers; third, the reservoir rock must have sufficient porosity to contain large quantities of water; and fourth, effective reservoir permeability must permit the delivery of tens of thousands of barrels of water per day, per well.

Knowledge of geopressured formations has resulted from years of exploration drilling for oil and gas, and the general geologic factors involved appear to be understood. Reservoirs of a type expected to be of value to exploitation of this resource, however, are not well known. The only production experience in abnormally pressured rock is from a relatively small number of natural gas fields; since gas wells do not generally present the same requirements as geothermal wells, directly transferable reservoir information is limited. Nevertheless, experience in these gas fields provides the basis for the best preliminary assessment of the production of this resource that exists.

The purpose of this paper is to report on a detailed investigation of one of the promising Gulf Coast geopressured areas in an attempt to assess the existence of favorable conditions for geothermal production.

\section{STUDY REGION}

The region in which this study has been conducted is in extreme South Texas, encompassing Cameron, Willacy, Hidalgo and the southern half of Kenedy counties. It was chosen because geopressures at moderate depths are known to exist throughout the area, and the temperature gradient is among the highest in the Gulf Coast Basin. The region has produced oil and gas prolifically since the 1930's. Moreover, the geothermal potential has been 
under geologic investigation for several years by the USGS and others. No comprehensive investigition of reservoir parameters has previously been reported.

The region is known as the Lower Rio (irande Valley of Texas. The economy, except for oil and gas production, is largely agricultural. Population density is low, with Brownsville the largest city and McAllen the next largest city, both having populations less than 50,000. The terrain is that and relatively featureless and is bordered on the east by the Gulf of Mexico and on the south by the Republic of Mexico.

Ilistorically, most of the geopressured production in this region has been confined to Hidalgo County. Of the 24 geopressured fields that have been identified in the study area, twenty are in Hidalgo County. The locations of these fields are shown in Figure 1.

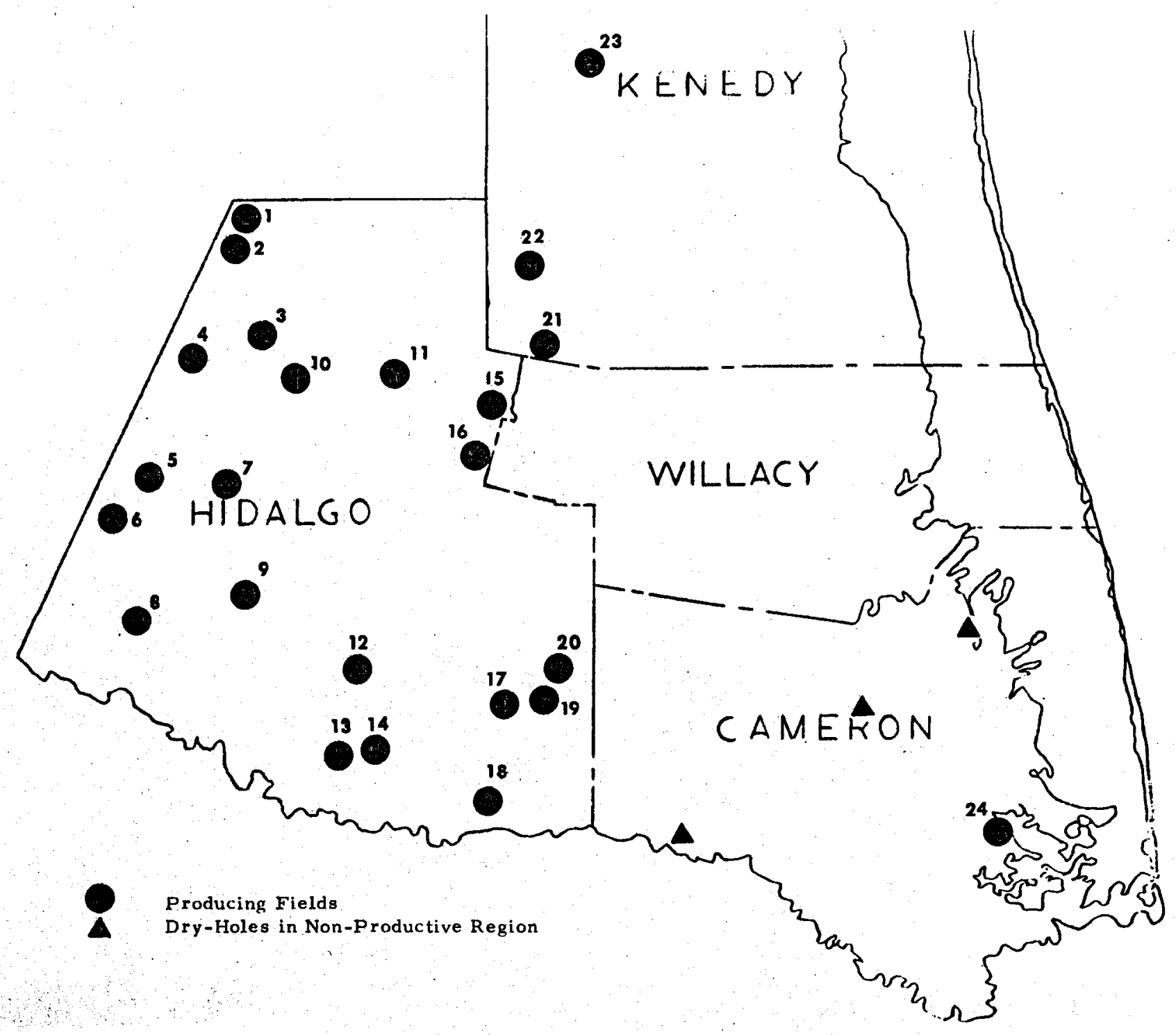

FIGURE 1. PRODUCING GEOPRESSURED GAS FIELDS IN TEXAS LOWER RIO GRANDE VALLEY 


\section{GEOLOGIC SETTING}

South Texas is dominated by a series of major growth-fault systems, generally parallel to the Coast. Four of these are considered major systems, with a large number of smaller fault blocks of great complexity. The four major systems are shown in Figure 2.
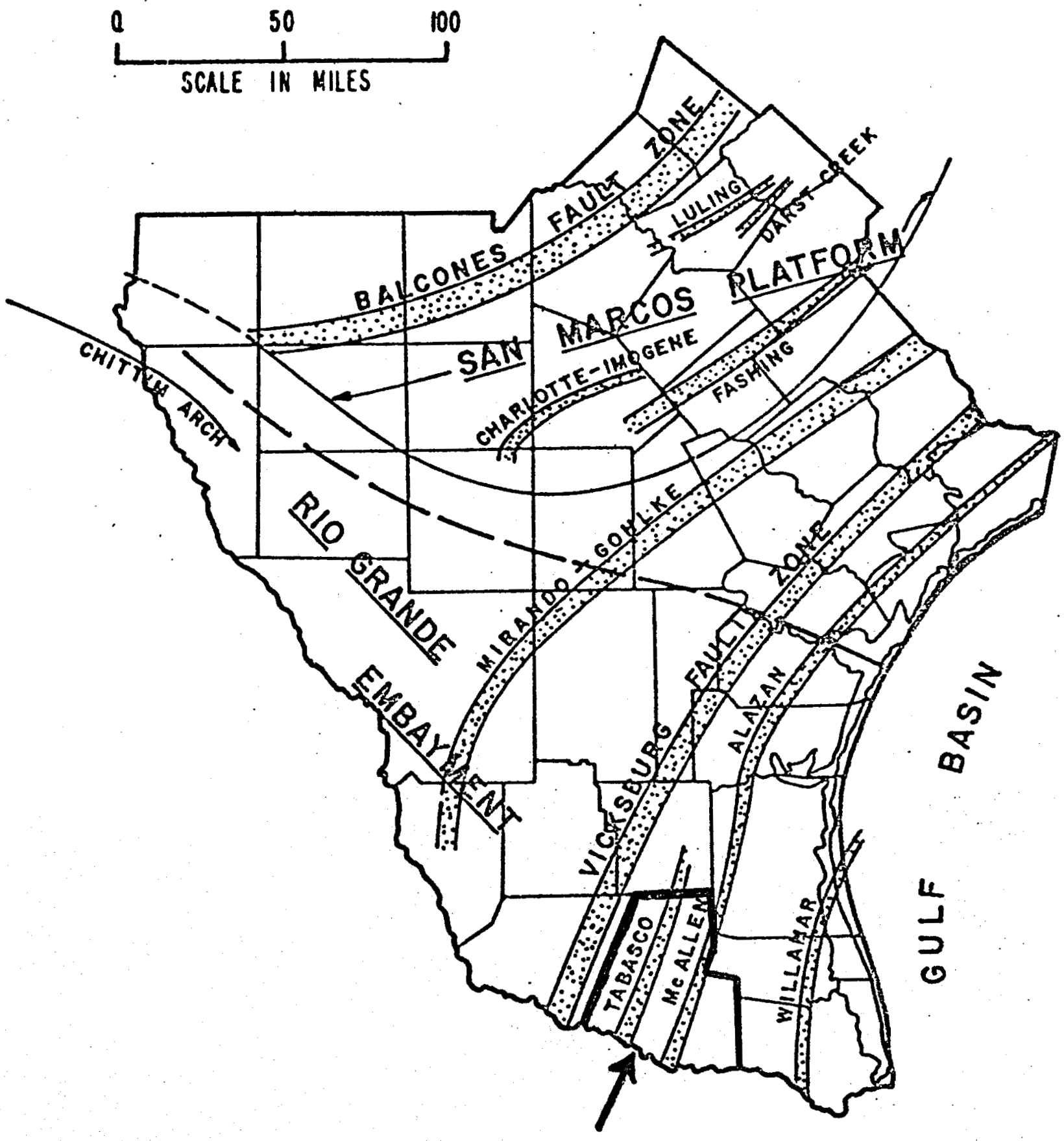

FIGURE 2. HIDALGO COUNTY (arrOW) IN RELATION TO-

1. VICKSBURG FAULT (Frio-Vicksburg Flexure)

2. TABASCO FAULT, AND

3. MCALLEN FAULT 
The productive geopressured fields identified in Hidalgo County are evenly distributed throughout the county under the control of three of the major fault systems in the area:

(1) The Frio-Vicksburg flexure in eastern Starr County near the Hidalgo County border,

(2) the Tabasco Fault,

(3) the McAllen Fault.

The Frio and Vicksburg formations on this trend are of Oligocene age and are the remnants of vast clastic deltaic sediments deposited by the ancestral Rio Grande River and accumulated as overlapping, irregularly lenticular sedimentary masses, reworked by longshore currents into an extensive system of barrier bars. Across the Frio-Vicksburg flexure, both the Frio and particularly the Vicksburg formations are greatly thickened. In the western half of Hidalgo County, the best Vicksburg sand development known on the Gulf Coast occurs. This sand deposition extends along and near the flexure region, from Hidalgo through Brooks into western Kleberg County. Nowhere is the Vicksburg more productive of gas and oil than in this region.

The Frio formation, which dominates the accessible geopressured horizon in eastern Hidalgo County, has been under study by the state Bureau of Economic Geology for the past two years. The Frio generally dips toward the Coast, thickening greatly across Cameron County to the east. Local conditions of reversed dip are frequent, however, and play a significant role in the occurrence of thick sand deposition in many of the areas of interest.

Two particular producing areas will be discussed in this paper. These are the McAllen Ranch Field in northwestern Hidalgo County and the Pharr-McAllen-Edinburg area in the south central part of the county. McAllen Ranch is important because it is representative of the six geopressured fields near the Frio-Vicksburg flexure. McAllen-Edinburg is of great significance, mainly because it represents the best large-scale sand deposition identified in the county.

\section{OCCURRENCE OF GEOPRESSURE}

Geopressure is evidently a general feature of deeper sediments in Hidalgo County and occurs at relatively uniform depths. The shallowest occurrence recorded is in the Jeffress Field, near the western boundary of the county, at 6,000 feet. This is unusual, however, and the top of the zone in that area is generally found at depths between 7,000 and 8,000 feet, dipping to about 10,500 feet toward the eastern county boundary and into Cameron County.

Geopressured production was located only in one field in Cameron County, near the coast, producing from Miocene sediments. Deep wildcats near the central axis of Cameron County have penetrated the geopressured zone, however; at depths ranging from 10,000 to 12,000 feet. In Kenedy County the depth of the zone is more variable, although apparently geopressure is a general feature there as well.

No particular significance is so far attached to detailed local variations in the depth of the geopressured zone. Frequently, the top of the zone is coincident with a particular 
lithologic marker over a fairly large area and a map of the "top of geopressure" simply defines that boundary. A case in point is the "8500" sand (Frio) in the McAllen-Pharr area. This is . a blanket sand, frequently productive, that always signals the first occurrence of abnormal pressures in the field. Its depth varies by only a few hundred feet over the field.

\section{TEMPERATURE}

Temperature data were obtained from well logs in each of the geopressured fields and from a random sample of dry holes across the region. Temperature readings from log headings were corrected to equilibrium values from the AAPG developed relation

$$
T_{E}=T_{L}-8.819 \times 10^{-12} D^{3}-2.143 \times 10^{-8} D^{2}+4.375 \times 10^{-3} D-1.018
$$

where

$$
\begin{aligned}
& T_{E}-\text { equilibrium temperature, }{ }^{\circ} \mathrm{F} \\
& T_{L}-\text { electric log bottom hole temperature, }{ }^{\circ} \mathrm{F} \\
& D \quad-\text { Depth, feet }
\end{aligned}
$$

These corrected values were used to calculate the depth of a $300^{\circ} \mathrm{F}$ isogeothermal surface from the measured temperature gradients. A computer program was written to correct each temperature reading from a log heading to the equilibrium value; to compute the gradient over each log run; to compute the overall gradient from average surface ambient to total depth; and to calculate the $300^{\circ} \mathrm{F}$ geotherm from the gradient at depth. A representative value of the depth of this surface was assigned for each of the geopressured fields. These depths are given in Table I, together with representative depths of the geopressured zone and typical reservoir parameters.

The depth of the $300^{\circ}$ geotherm is fairly uniform across Hidalgo County, ranging from about 10,500 to 13,500 feet. There are wide local variations within this range. If the surface is plotted in detail, patterns of great complexity emerge, no doubt reflecting the effect of countless major and minor growth faults that characterize the region. This is illustrated in Figure 3, which is a detailed contour map of the $300^{\circ}$ surface over the McAllen-Pharr-South Edinburg area. Note that the isothermal surface is warped downward over each of the four major structures defining these fields.

\section{MCALLEN RANCH FIELD}

McAllen Ranch is a Vicksburg gas field in Western Hidalgo County, with geopressured gas production occurring at depths generally from 10,000 to 12,000 feet. It is typical of deep Vicksburg production occurring along the Frio-Vicksburg flexure in northwestern Hidalgo County. Similar fields are Kelsey East, McMoran, Arrowhead, McCook and Jeffress. Sand bodies, represented on the McAllen Ranch type-log in Figure 4, are typically shaley and extremely fine grained. Porosity and permeability are low. 
TABLE 1. REPRESENTATIVE RESERVOIR PARAMETERS FOR SOUTH TEXAS GEOPRESSURED GAS FIELDS

\begin{tabular}{|c|c|c|c|c|c|c|}
\hline \multirow{2}{*}{ Field } & \multirow{2}{*}{$\begin{array}{l}\text { Approx. Depth, } \\
\text { Top Geopressure }\end{array}$} & \multirow{2}{*}{$\begin{array}{l}\text { Approx. Depth, } \\
300^{\circ} \text { Geotherm }\end{array}$} & \multirow[b]{2}{*}{$\mathbf{k h}$} & \multicolumn{2}{|c|}{ Effective Permeability } & \multirow{2}{*}{$\begin{array}{c}\text { Water Salinity, } \\
\text { ppm Cl }\end{array}$} \\
\hline & & & & md at & Depth & \\
\hline $\begin{array}{l}\text { 1.* Kelsey } \\
\text { 2. McMoran } \\
\text { 3. McAllen Ranch } \\
\text { 4. Arrowhead } \\
\text { 5. McCook } \\
\text { 6. Jeffress } \\
\text { 7. Monte Christo } \\
\text { 8. Foy } \\
\text { 9. Oblate } \\
\text { 10. Santellana } \\
\text { 1. Cerda } \\
\text { 12. S. Edinburg } \\
\text { 13. McAllen } \\
\text { 14. Pharr } \\
\text { 15. La Jara } \\
\text { 16. Hargill } \\
\text { 17. N. Weslaco } \\
\text { 18. S. Weslaco } \\
\text { 19. SW Mercedes } \\
\text { 20. Mercedes } \\
\text { 21. Tordilla (Kenedy Co.) } \\
\text { 22. Stillman (Kenedy Co.) } \\
\text { 23. Candelaria (Kenedy Co.) } \\
\text { 24. San Martin (Cameron Co.) }\end{array}$ & $\begin{array}{r}8,500 \\
8,500 \\
7,500 \\
11,000 \\
7,700 \\
7,000 \\
8,600 \\
10,100 \\
9,700 \\
8,000 \\
10,200 \\
9,300 \\
8,500 \\
8,700 \\
9,600 \\
10,000 \\
9,600 \\
9,400 \\
9,400 \\
9,450 \\
9,480 \\
9,500 \\
11,000 \\
9,000\end{array}$ & $\begin{array}{l}11,400 \\
11,600 \\
11,700 \\
11,800 \\
11,200 \\
11,700 \\
10,674 \\
11,000 \\
12,000 \\
11,500 \\
11,400 \\
11,500 \\
12,500 \\
12,000 \\
12,400 \\
13,400 \\
11,600 \\
12,000 \\
12,600 \\
12,500 \\
12,800 \\
12,000\end{array}$ & $\begin{array}{r}5.4 \\
48.3 \\
29.4 \\
29.8 \\
22.7 \\
88.0 \\
2.04 \\
20.5 \\
1.72 \\
20.0 \\
50.5 \\
47.0 \\
9.5 \\
14.11 \\
0.64 \\
15.7 \\
38.0 \\
20.2 \\
2.7 \\
5.5 \\
3.0 \\
20.2 \\
31.8 \\
8.4 \\
23.9\end{array}$ & $\begin{array}{l}0.27 \\
0.69 \\
0.60 \\
0.65 \\
0.1 \\
0.2 \\
0.12 \\
1.0 \\
1.0 \\
2.0 \\
5.05 \\
0.8 \\
0.20 \\
0.35 \\
0.01 \\
0.9 \\
2.2 \\
2.0 \\
1.0 \\
1.0 \\
1.0 \\
1.26 \\
8.0 \\
0.55 \\
3.4\end{array}$ & $\begin{array}{r}11,992 \\
9,033 \\
10,119 \\
11,988 \\
12,580 \\
11,900 \\
10,081 \\
9,675 \\
11,356 \\
8,460 \\
10,074 \\
11,214 \text { (Marks) } \\
11,218 \text { (Bond) } \\
9,880 \text { (Marks) } \\
13,788 \text { (Kelly) } \\
10,080 \\
10,046 \\
10,252 \\
9,400 \\
10,600 \\
9,480 \\
10,480 \\
9,409 \\
10,090 \\
9,392 \text { (Miocene) }\end{array}$ & $\begin{array}{r}36,400 \\
9,300 \\
15,500 \\
6,000\end{array}$ \\
\hline \multicolumn{7}{|c|}{ Deep Dry-Holes in Cameron County } \\
\hline $\begin{array}{l}\text { Pan Am Wentz \#1 } \\
\text { Shell Cont. Fee \#1 } \\
\text { Chevron Rodriguez \#1 }\end{array}$ & $\begin{array}{l}10,200 \\
12,300 \\
12,000\end{array}$ & $\begin{array}{l}13,955 \\
12,970 \\
14,939\end{array}$ & & & & \\
\hline
\end{tabular}




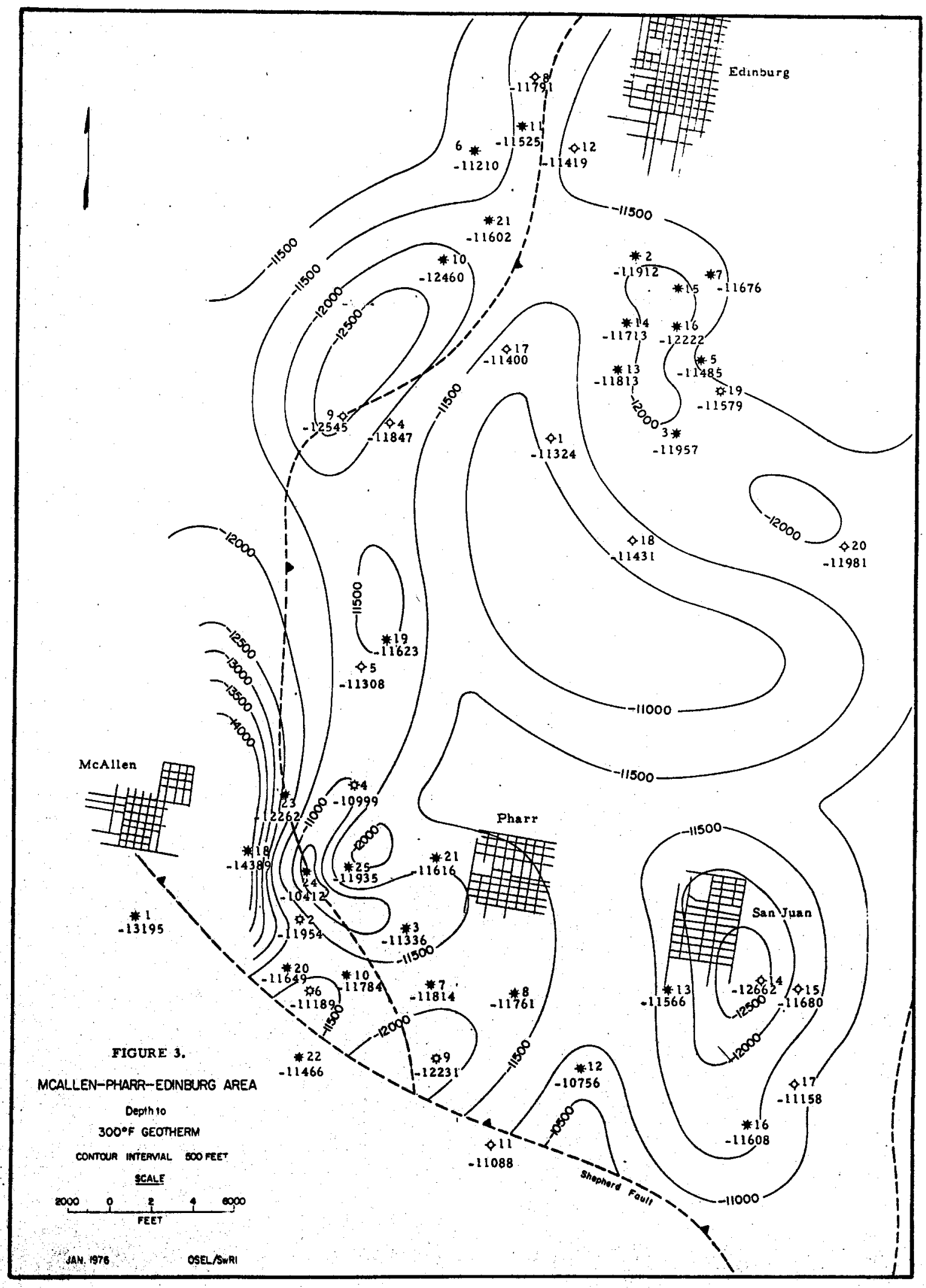

FIGURE 3. MCALLEN-PHARR-EDINBURG AREA

Depth to $300^{\circ} \mathrm{F}$ Geotherm (Contour

Interval 500 Feet) 


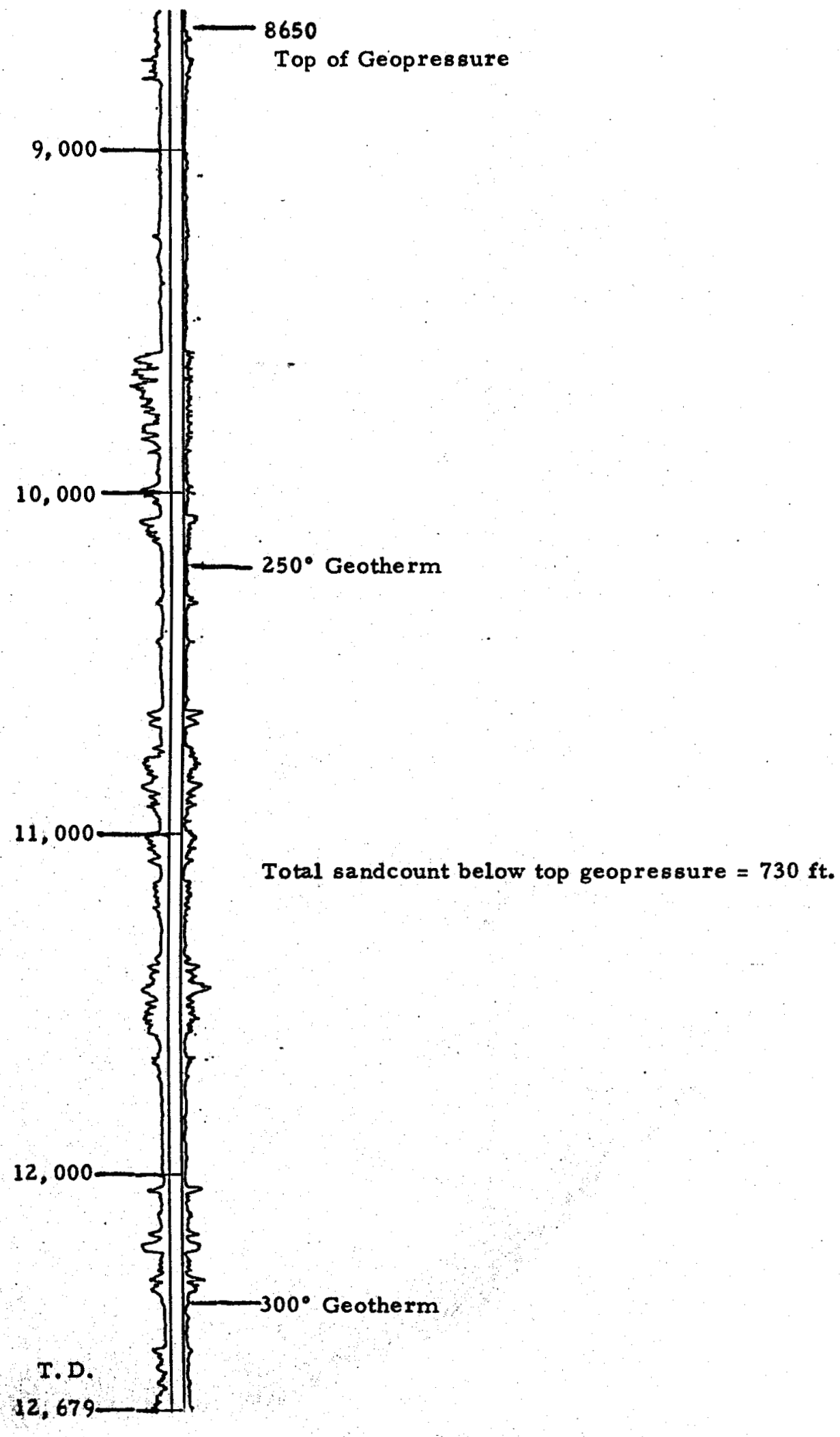

FIGURE 4. LOG OF GEOPRESSURED SEDIMENTS, MCALLEN RANCH FIELD, HIDALGO COUNTY, TEXAS 
The gas reservoirs are small in area, generally bounded by systems of highly complex faulting and lenticular sand development. Evidence of large, continuous aquifers in any of these fields has not been located, although total depth of sand deposition is extensive. The type-log shows at least 730 feet of total sand from the top of geopressure to 12,676 feet in McAllen Ranch. The geothermal gradient averages about $2^{\circ} \mathrm{F} / 100$ feet $\left(3.65^{\circ} \mathrm{C} / 100 \mathrm{~m}\right)$ and the depth of the $300^{\circ} \mathrm{F}\left(150^{\circ} \mathrm{C}\right)$ isogeothermal surface is near 12,000 feet.

\section{PHARR-McALLEN-EDINBURG AREA}

From the geological evaluations made thus far in this study, one promising area for the occurrence of continuous, geopressured sand sections of broad areal extent is located in the McAllen-Pharr-Edinburg area. Here, Collins (1968) points out that the vast amount of deposition associated with the Rio Grande Embayment and the huge contemporaneous McAllen Fault System created one of the significant features characteristic of this area-"reverse dip" into the McAllen Fault, together with the associated thickening of the affected formations. These include the potential geothermal reservoirs.

The McAllen-Pharr and South Edinburg fields are situated between two north-south trending fault systems, the McAllen Fault and the Donna Fault. The sedimentation and structure of the area were controlled primarily by the massive McAllen growth fault to the west of the fields but in part by the relatively stable area created to the east by the Donna Fault. The east-west trending Shepherd Fault, with several thousand feet of throw, limits the fields on the south. A type-log of McAllen-Pharr is shown in Figure 5.

Gas and gas condensates have been produced from more than a dozen Frio-Vicksburg sands between the depths of 5,800 feet and 13,700 feet. In the upper portion of the geopressured section (Hansen Sand), the production occurs in a large stratigraphic trap; deeper production is from small fault blocks, with the beds dipping generally away from the basin. Of principal interest in this study are the lower Frio-Vicksburg sands of the Marks and Bond series and below, where the temperatures are in the range of $300^{\circ} \mathrm{F}$ and higher. The Marks and Bond series contain as much as 800 feet of sand, with some individual sand beds more than 100 feet in thickness. According to Collins, most of the faults do not disrupt the continuity of the aquifers because the thickness of the sands is greater than the throw of the faults. Generally, the individual stratigraphic units can be correlated between fields suggesting a potential sand source of 20 to 30 square miles or even more.

Figure 6 is a structure map on the top of the Marks sand on which two such potential aquifers are outlined. Here, correlation between McAllen-Pharr and South Edinburg fields is so definite as to strongly suggest continuity over the area between, even though direct control is limited.

\section{DRILLING CONSIDERATIONS}

Drilling wells which penetrate the geopressured zone is more difficult than drilling wells to the same depth in normally pressured formations. An intermediate casing string usually must be set before total depth is reached, and its placement is very critical. If the intermediate casing is set at too shallow a depth, controlling mud weight to contain deeper, 


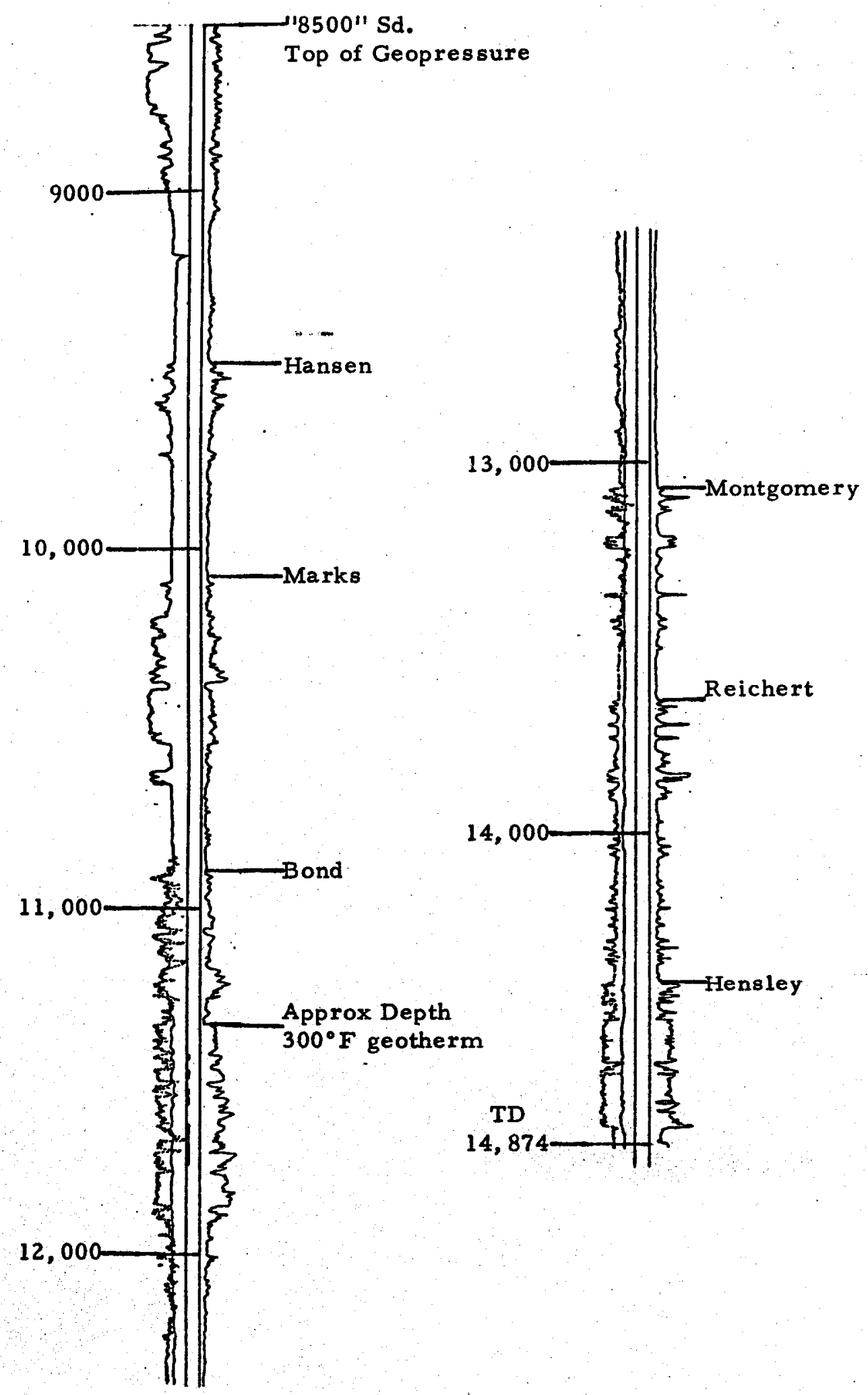

FIGURE 5. WELL LOG OF DEEP, GEOPRESSURED SANDS IN MCALLEN FIELD, HIDALGO COUNTY, TEXAS 


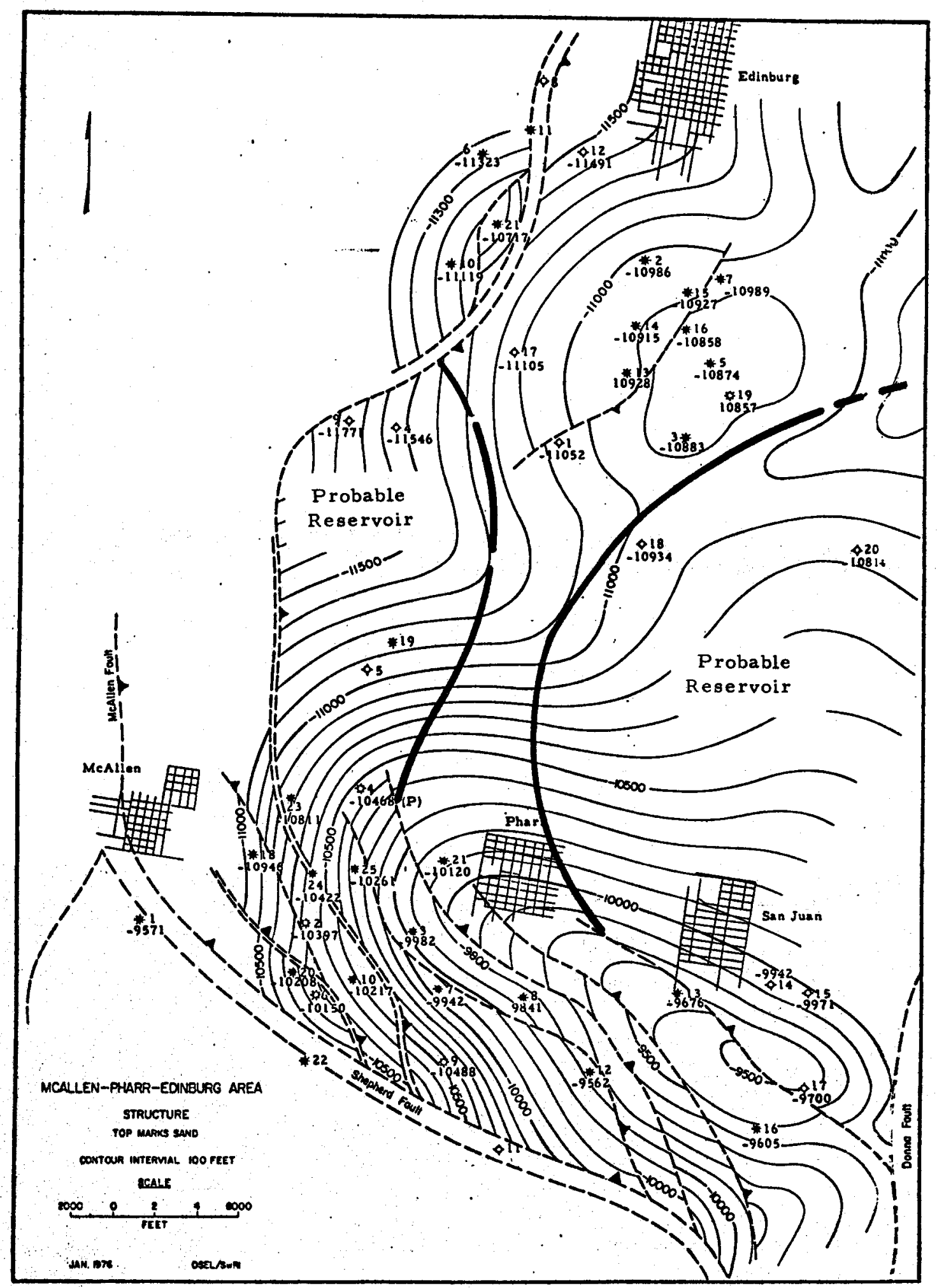

FIGURE 6. MCALLEN-PHARR-EDINBURG AREA STRUCTURE (Top Marks Sand-Contour Interval 100 Feet) 
abnormally pressured formations is likely to cause normally pressured formations to break down, resulting in "lost circulation". In addition, the temperatures in the South Texas geopressured zone are higher than those normally encountered at equivalent depths elsewhere. These elevated temperatures require greater care and expense in maintaining the drilling mud system. In addition, completion equipment, logging instruments, and other down-hole tools run in the well require extra attention and even special design. Nevertheless, hundreds of deep, abnormally pressured wells have been drilled, logged, the formations tested, and completions successfully accomplished.

Geothermal production wells in a region like South Texas will be more costly than gas and oil wells in the same formations, partially due to the need for large production tubing. For example, a typical casing program in an Edinburg or McAllen gas well would call for surface pipe, then an intermediate 7-in. casing string to 8,500 to 9,000 feet, followed by a 5-1/2-in. production string to producing sands at 9,500 to 14,000 feet. A geothermal well in the same area would certainly require a 9-7/8-in. production string to equivalent depths, preceded by at least a 12-in. intermediate string. Few drilling ventures in the Texas Gulf Coast area have ever attempted such a casing program.

\section{RESERVOIR PARAMETERS}

To demonstrate the reservoir properties of a South Texas well to supply geothermal fluid at a rate of 100,000 barrels a day for 20 years, consider a hypothetical well drilled in the McAllen-Edinburg area. The well drilled to 12,000 feet, and cased with 9-5/8-in. casing, will encounter a bottom-hole pressure of $10,000 \mathrm{psi}$. The circular reservoir will be conservatively assumed to have a radius of 9,326 feet, or roughly 2 miles. The surface area will then be 6,273 acres or 9.8 square miles. The thickness of the producing interval is assumed to be 500 feet, the compressibility $2 \times 10^{-4}$, and the permeability of the formation, 100 millidarcies. The cost to drill and complete such a well would be a minimum of $\$ 1,200,000$ without contingency considerations.

The pressure produced by the hydrostatic head of water in the well bore will be $5,200 \mathrm{lb}$. When the well is flowed, this pressure will be reduced somewhat by the evolution of dissolved methane from the water. On the other hand, the evolution of methane from the brine within the pores of reservoir rock will tend to interfere with the flow of brine to the well bore. The benefit derived from the gas lifting and the reduction of permeability from the gas released in the reservoir will be assumed to offset each other. The pressure performance of this well at the surface, producing at a rate of $100,000 \mathrm{bbl}$ of water per day after a short transient period, is presented in Figure 7. During the initial transient period which lasts for 3.8 years, the flowing pressure will be held to 3,288 psi. After 3.8 years, the pressure will linearly decline so that in 20 years the pressure will be 97 psi.

We now examine the South Texas area to determine if a reservoir with the assumed properties, capable of producing hot water for a period of 20 years at a rate of $100,000 \mathrm{bbl}$ per day, can be found. 


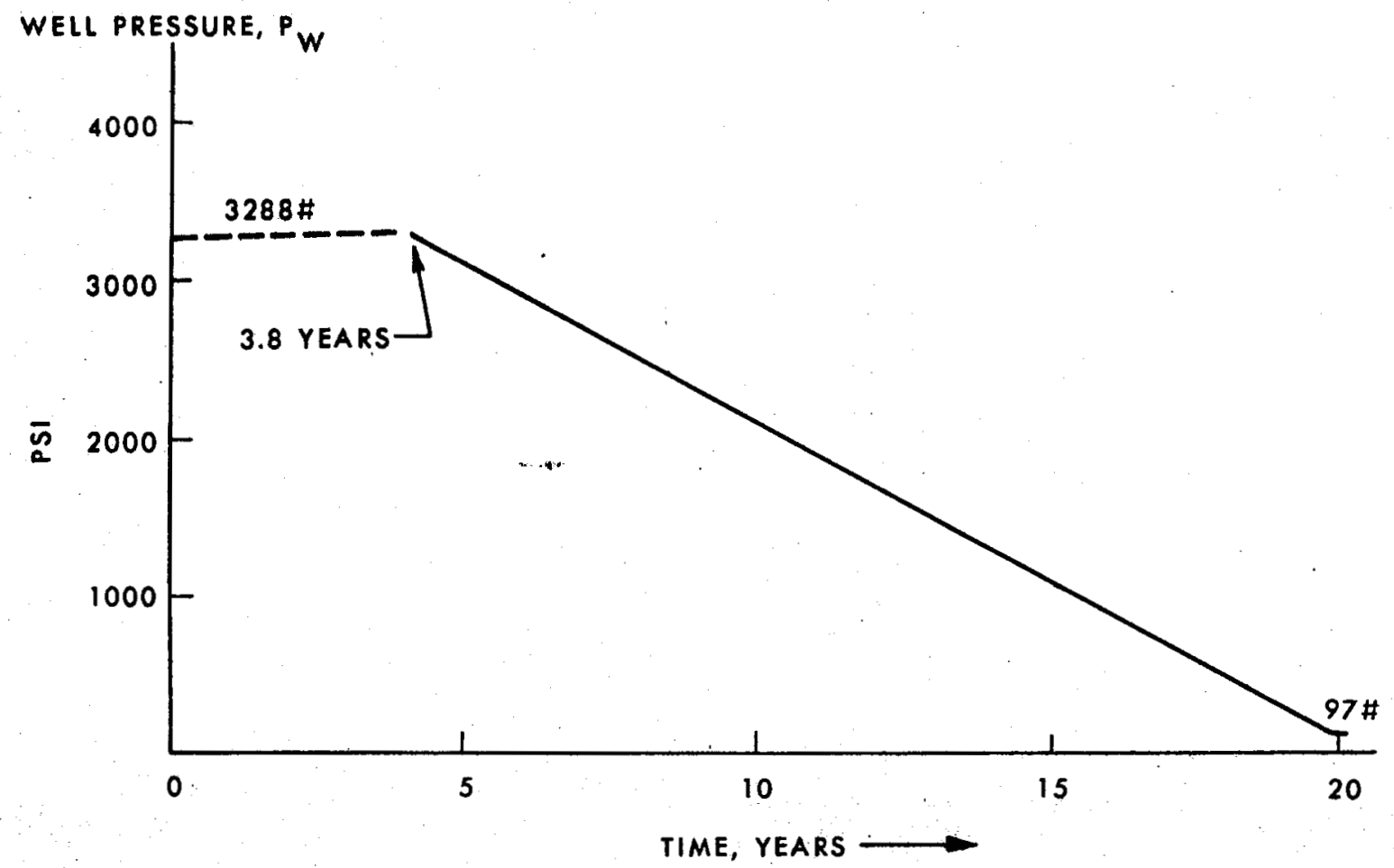

FIGURE 7. LONG-TERM WELL PRESSURE BEHAVIOR IN A WELL CAPABLE OF PRODUCING GEOPRESSURED-GEOTHERMAL ENERGY

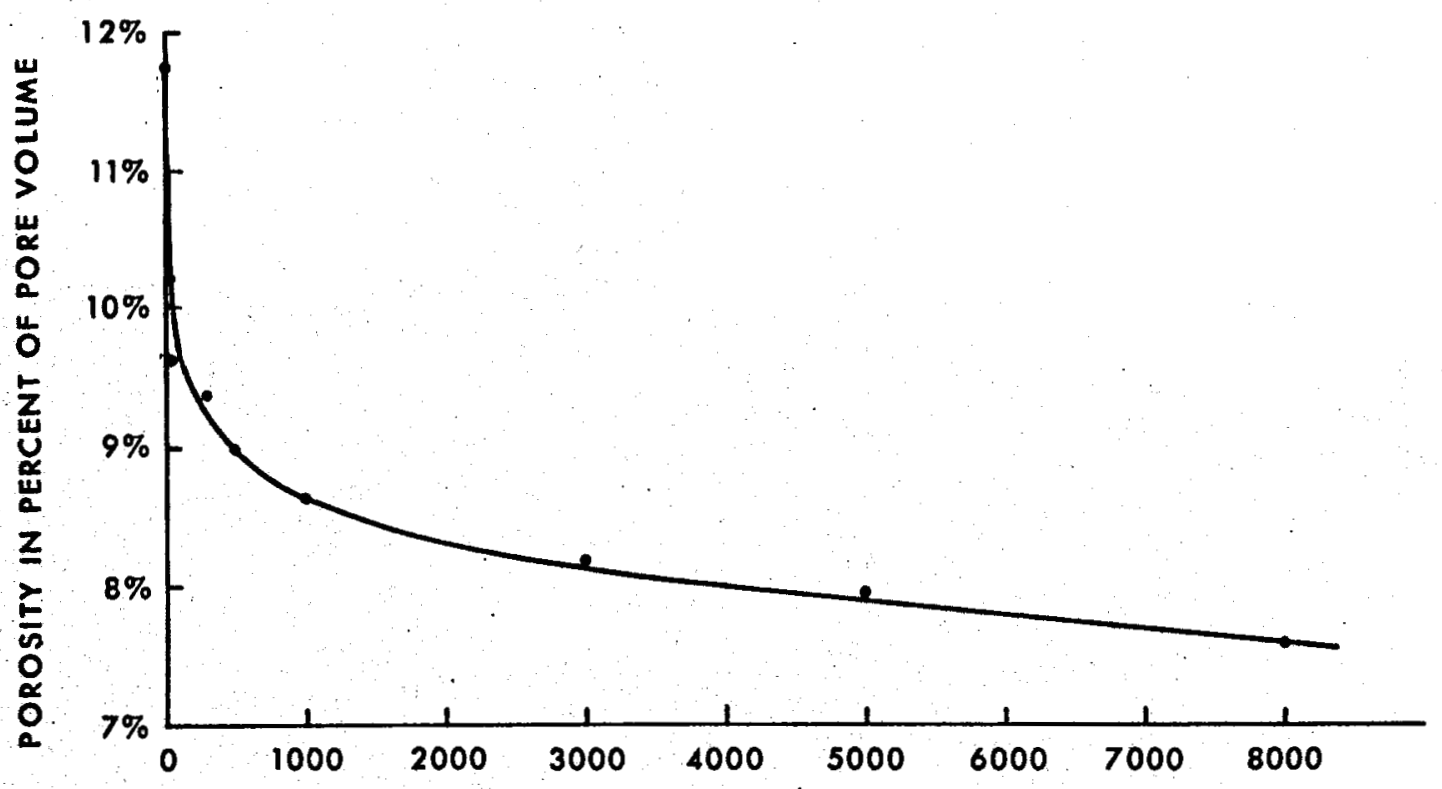

CONFINING PRESSURE IN PSI

FIGURE 8. COMPRESSIBILITY OF A CORE FROM A GEOPRESSURED RESERVOIR 


\section{COMPRESSIBILITY}

In the hypothetical reservoir, the compressibility was assumed to be $2 \times 10^{-4}$. We are unable to find data at this time describing the porosity behavior as a function of confining pressure for reservoir rock from the South Texas area. However, in Figure 8 the results of the measurement of porosity of rock versus confining pressure from an abnormally pressured formation in California are shown. It is not likely that the behavior of the South Texas field would be identical to the California fields, but it is likely that the usual figures of $5 \times 10^{-6}$ to $10^{-5}$ given in most geopressure discussions are too low, to the detriment of the predicted results. We believe much higher compressibility values can be counted on. If the compressibility of the hypothetical reservoir is truly only $10^{-5}$, the value associated with normally pressured, consolidated reservoirs, the pressure will drop to zero in the South Texas well after one year's production at a rate of $100,000 \mathrm{bbl}$ of water per day.

\section{DEPTH}

The hypothetical South Texas well was assumed to be $12,000 \mathrm{ft}$ deep. From the study of temperatures in this area, it was noted that the depth of the $300^{\circ} \mathrm{F}$ geotherm varies from about 10,500 feet to 13,500 feet. Thus, the selection of $12,000 \mathrm{ft}$ for the depth of the producing well is reasonable, though probably a minimum value.

\section{FORMATION THICKNESS}

The thickness of potential geothermal producing intervals varies considerably over South Texas. However, a number of areas have been located in which sand thickness in excess of 500 feet can be relied upon. In the McAllen-Edinburg area, the thickness of the Marks-Bond series alone exceeds 500 feet over a considerable area. This requirement appears to be capable of achievement.

\section{AREAL EXTENT}

The surface area of the hypothetical reservoir was assumed to be 10 square miles. From geological study of the McAllen-Pharr-Edinburg area, it was concluded that this is a realistic assumption. Contiguous aquifers as much as 2 to 3 times that great may be located with some assurance.

\section{PERMEABILITY}

The most critical reservoir parameter in South Texas is permeability. Any South Texas geologist or petroleum engineer is extremely sensitive to the meaning of the term " 100 millidarcies" when applied to the deeper horizons of that area. For that reason the most extensive part of the study was devoted to an investigation of the permeability of existing reservoirs, utilizing information of all types from a variety of sources.

The permeability of a reservoir is normally determined in one of three ways: (1) from production and pressure behavior of a well; (2) from core analysis; ( 3 ) from buildup and draw-down tests. Probably the most reliable indication of effective permeability of a reservoir is obtained from buildup and draw-down tests. Often, however, and particularly from public records, these test results are not available. The information most readily available in most cases are the results of "four-point tests", in which bottom-hole pressure at four separate flow rates is measured. 
The rate of flow of gas from a gas well in a reservoir is given by the following empirical equation:

$$
Q_{b}=\frac{19.88 k h\left(P_{e}^{2}-P_{w}^{2}\right)}{\mu P_{b} \ln \frac{r_{e}}{r_{w}}}
$$

where

$$
\begin{aligned}
& Q_{b}-\text { cu } \mathrm{ft} \text { gas/day at base pressure } P_{b} \\
& k-\text { permeability darcies } \\
& h \quad-\text { formation thickness, } \mathrm{ft} \\
& P_{e}-\text { formation pressure at boundary distance } r_{e}, \mathrm{psi} \\
& P_{w}-\text { formation pressure flowing, at well, psi } \\
& r_{e}-\text { radius of reservoir, } \mathrm{ft} \\
& r_{w}-\text { radius of well, } \mathrm{ft} \\
& \mu \quad-\quad \text { viscosity of the gas }
\end{aligned}
$$

Representative permeability values calculated for the six deep fields along the Frio-Vicksburg flexure are shown on the map in Figure 9. The values are consistently less than 1.0 millidarcy, ranging from 0.1 to $0.69 \mathrm{md}$. These calculated values are confirmed by a suite of cores measured under confinement from the well represented by the type-log from McAllen Ranch shown previously in Figure 4. This well was cored almost continuously from 10,600 feet to 12,600 feet, and the data was made available by Shell Oil Company. The average permeability of all the samples was about 0.1 millidarcy. There were 13 samples in the entire suite of cores with permeabilities above 10 millidarcies. The highest permeability was 39 millidarcies over a $1 / 2$-foot core interval.

Figure 10 shows permeability values calculated for three geopressured fields in southwestern Hidalgo County along the Tabasco Fault trend. These values are also in the range of 1.0 to 0.1 millidarcy.

Northeastern Hidalgo-Southwestern Kenedy Counties form the location of five geopressured fields, with calculated permeability values ranging from 1.0 to 8.0 millidarcies, all in middle Frio sands along the northern extension of the McAllen fault. The locations are shown in Figure 11.

The two "outpost" fields in the study, Candelaria field in central Kenedy County and San Manuel field in Southeastern Cameron County, are shown in Figure 12. Permeability values range from $0.55 \mathrm{md}$ in Candelaria to $3.4 \mathrm{md}$ in the Miocene production zone in San Manuel.

Geopressured fields in the lower Hidalgo County area are shown on the map in Figure 13. South Edinburg, McAllen and Pharr are the three fields to the west, where the hypothetical "test well" is imagined to be. Effective permeabilities range from about $0.5 \mathrm{md}$ to $2.0 \mathrm{md}$. 


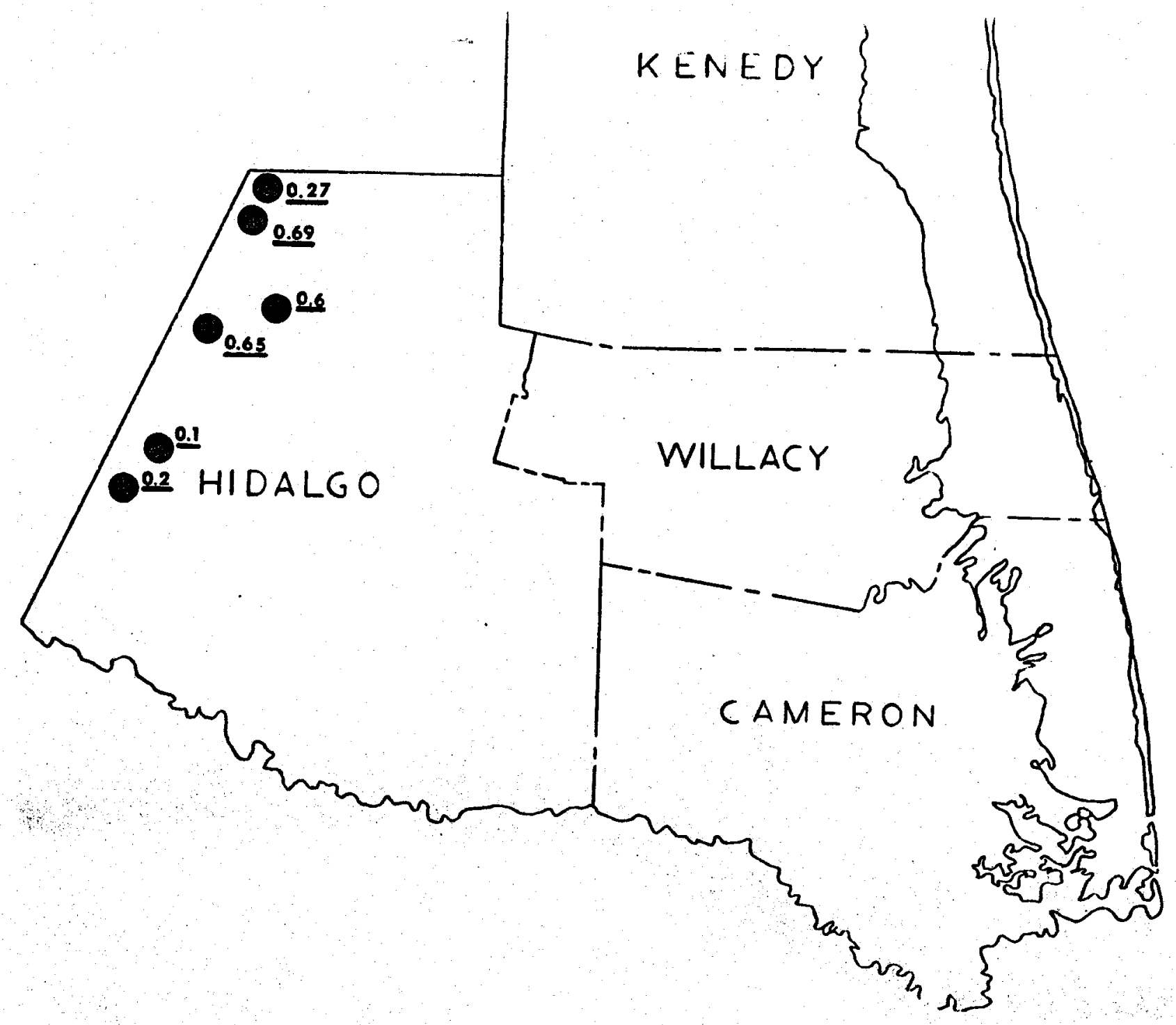

FIGURE 9. REPRESENTATIVE PERMEABILITY, md VICKSBURG FAULT AREA (VICKSBURG) 


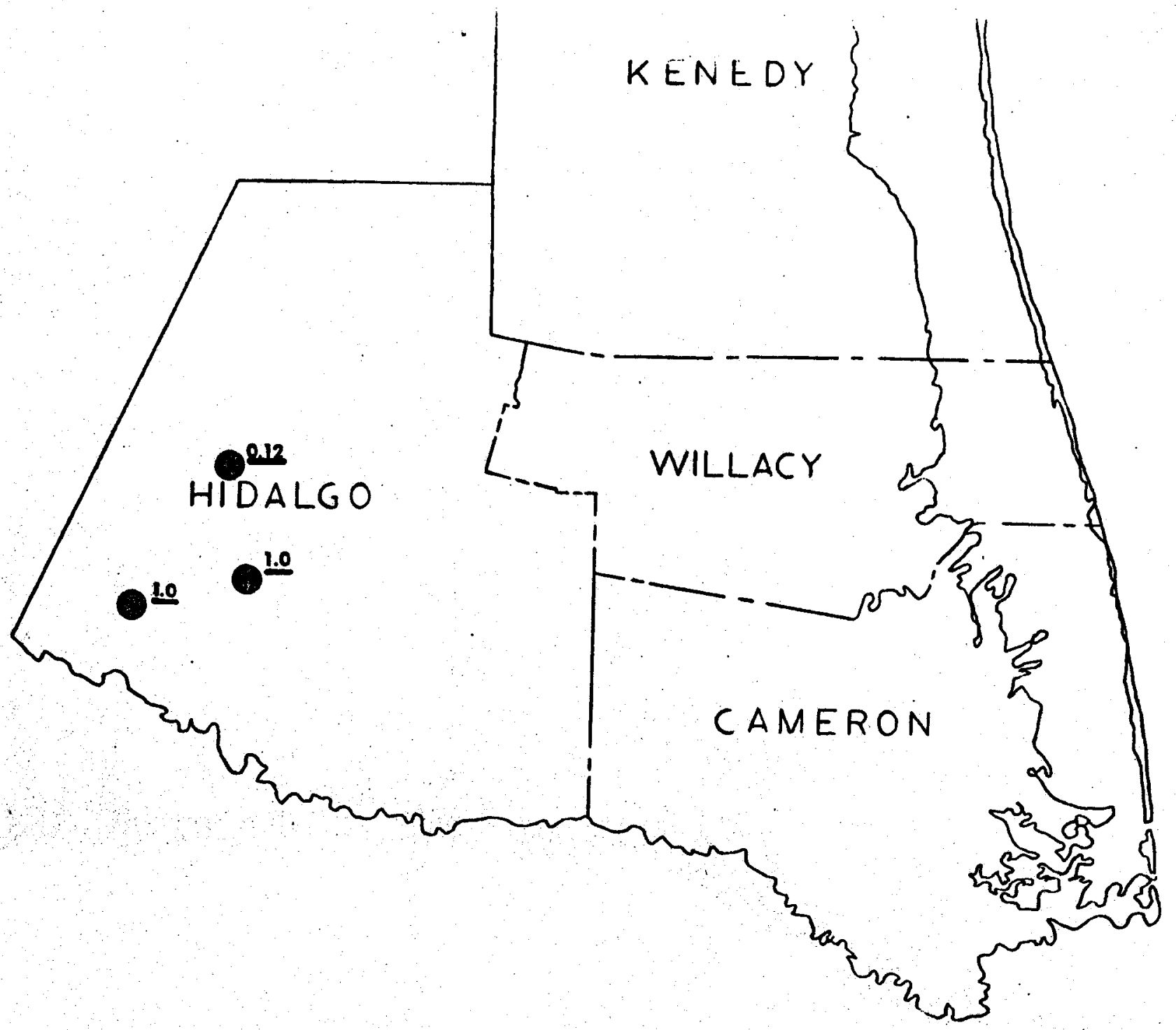

FIGURE 10. REPRESENTATIVE PERMEABILITY, md

TABASCO FAULT AREA (VICKSBURG) 


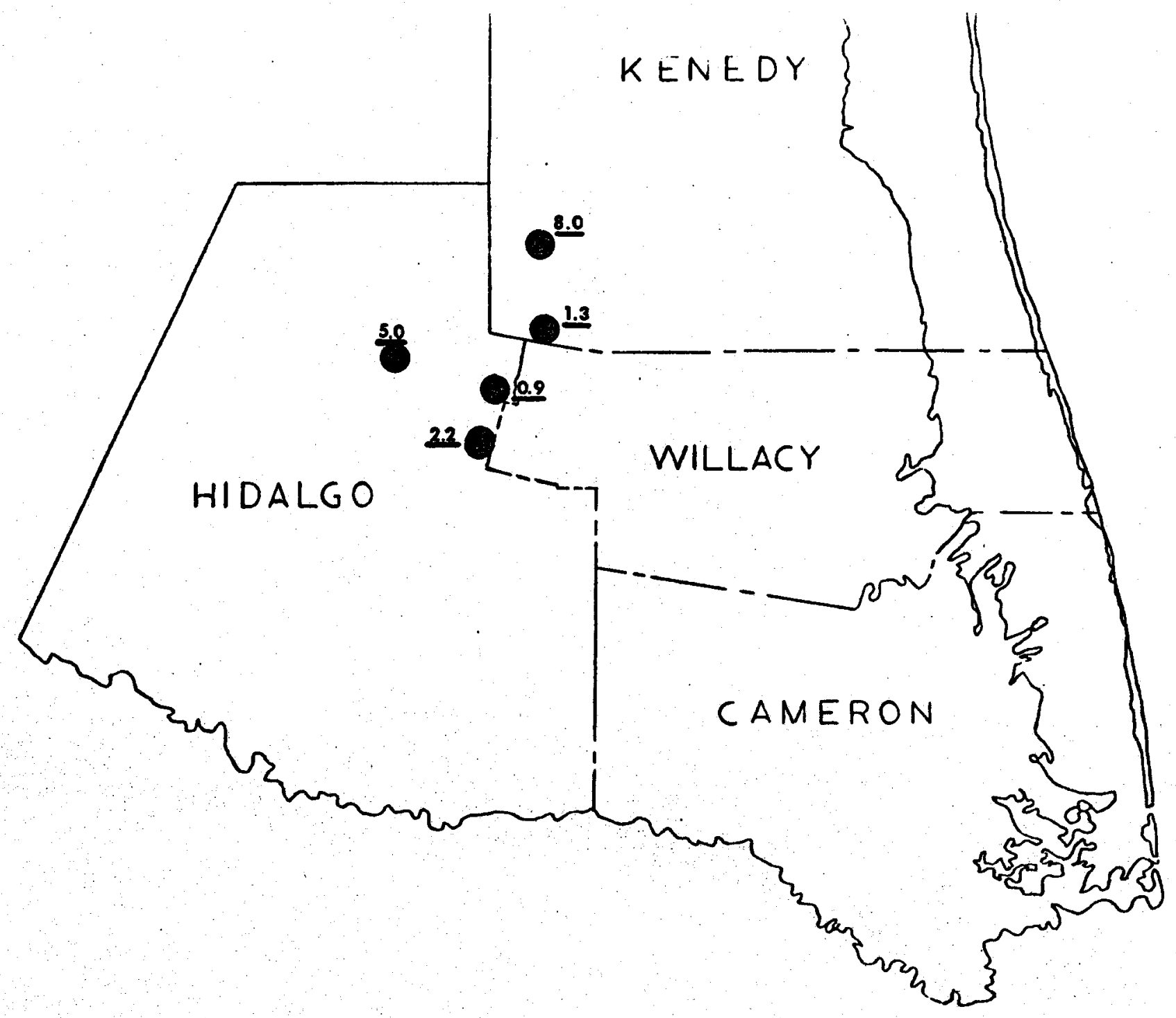

FIGURE 11. REPRESENTATIVE EFFECTIVE PERMEABILITY, md UPPER MCALLEN FAULT ZONE 


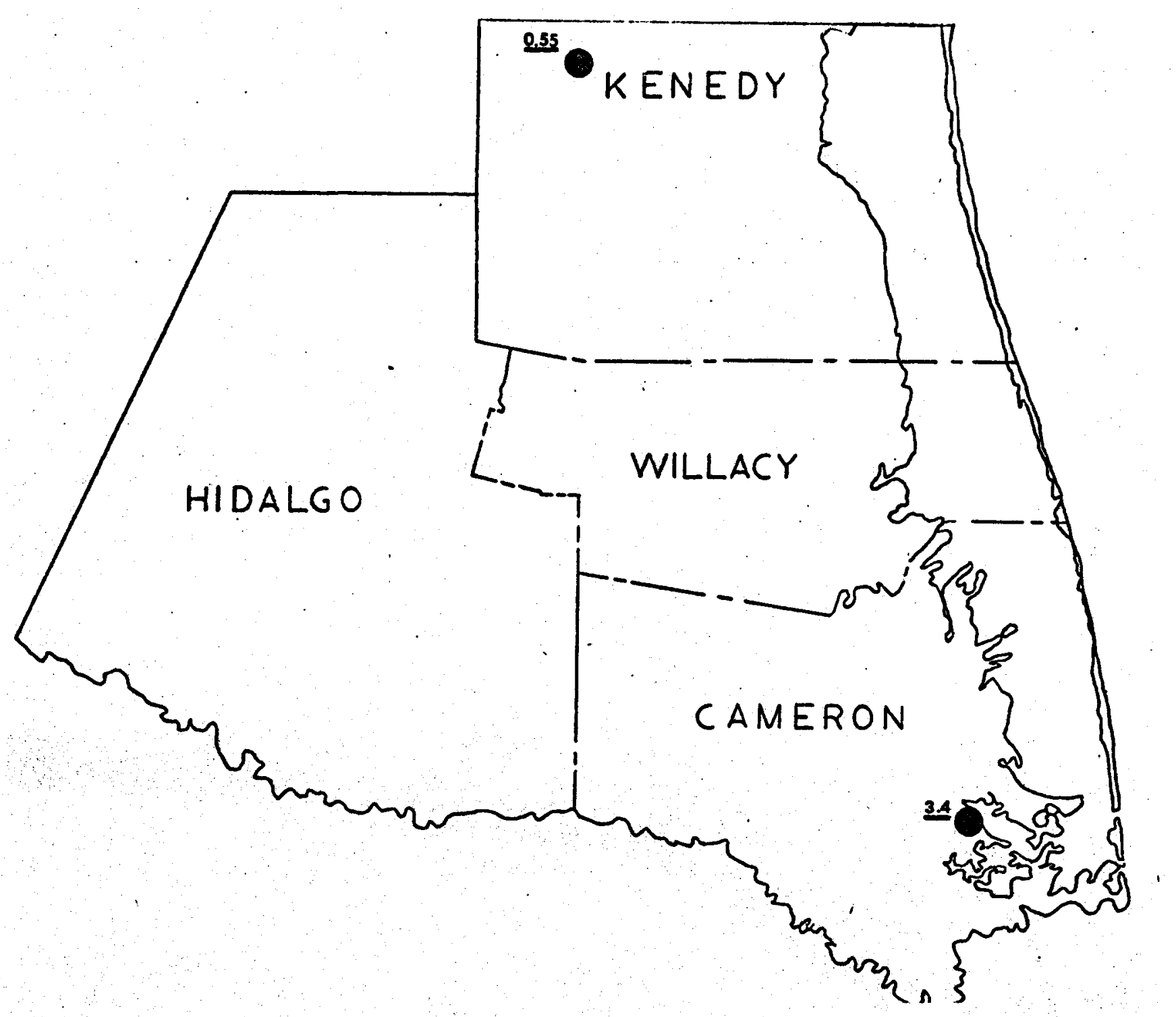

FIGURE 12. REPRESENTATIVE EFFECTIVE PERMEABILITY, md CENTRAL KENEDY AND EASTERN CAMERON COUNTY 


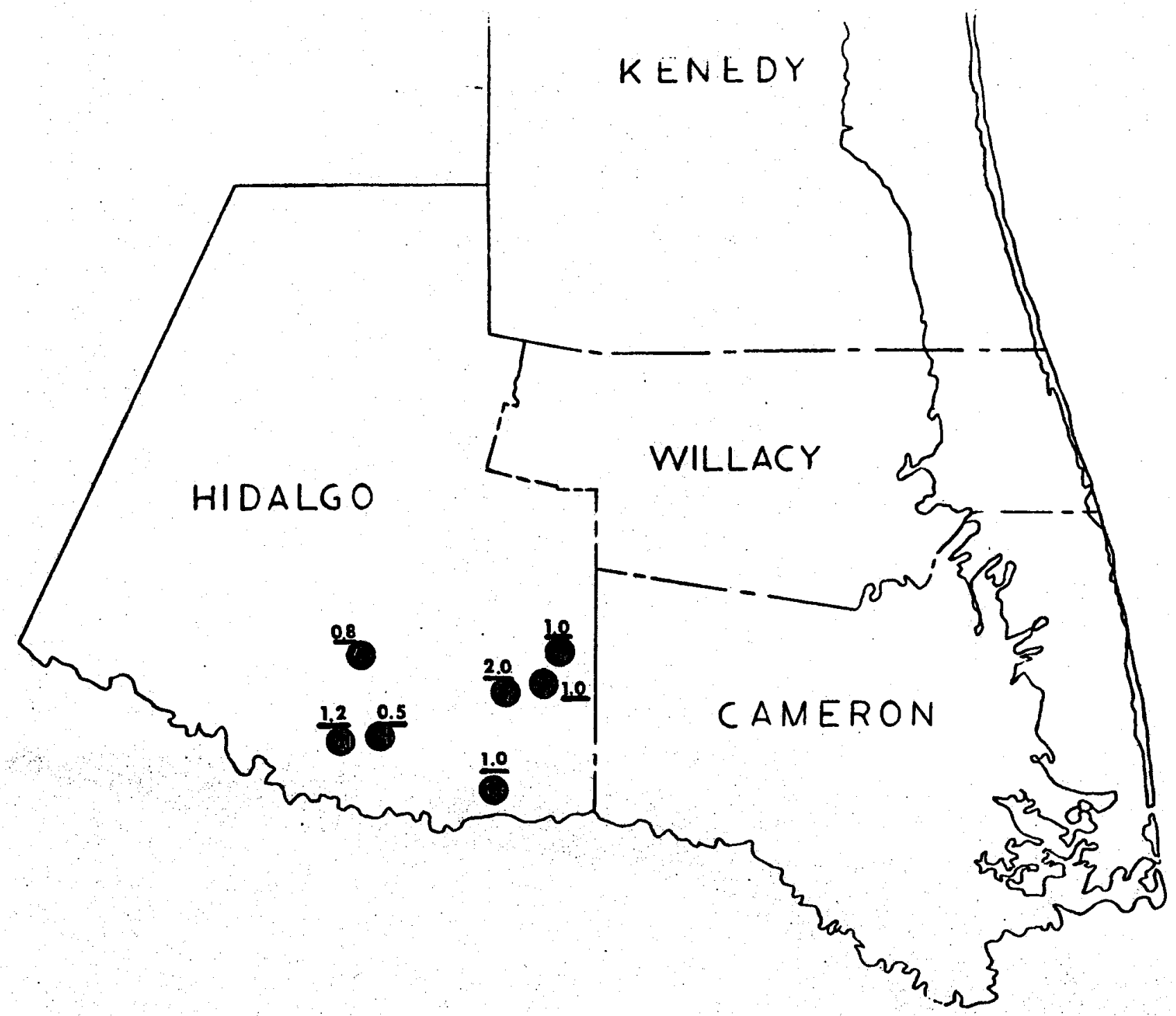

FIGURE 13. REPRESENTATIVE PERMEABILITY, md MCALLEN-EDINBURG AND WESLACO-

MERCEDES AREAS 
The effective permeability of a reservoir is a complex function of the overburden pressure. Generally, the effect of overburden pressure on samples of rock from reservoirs is such as to greatly reduce the effective permeability of the formation at depth. Figure 14 shows the permeability of a sample of reservoir rock from a geopressured California reservoir, subjected to pressure in the laboratory. As the confining pressure on the sample is increased, permeability is reduced by two orders of magnitude at high confining pressure.

One of the valuable features of the McAllen Field, for study purposes, is the large number of producing zones. In Figure 15 is a permeability profile of the McAllen-Pharr area, constructed from calculated permeabilities from a large number of these reservoirs from 6,000 feet to 13,800 feet in depth. The permeability is seen to drop consistently at a rate of nearly one order of magnitude for each 2,000 feet of depth over the entire range. Permeability values range from $16 \mathrm{md}$ above the geopressured zone to $0.03 \mathrm{md}$ at 14,000 feet.

The contrast of permeability measurements made on unconfined cores, compared with calculated values of effective permeability from production data, is graphically shown in Table II. Core permeability values from McAllen field range from $75 \mathrm{md}$ at 6,600 feet to $18 \mathrm{md}$ in the Bond sands at 11,500 feet, although calculated values of effective permeability in the same reservoirs are consistently lower, and drastically so.

There have been a number of deep drill-stem test results found during our study in zones that produced mostly water and some gas. Several of these tests were apparently in water sands in the deep geopressured zone in this area. In general, the characteristics of these reservoirs are such as to produce some gas, probably dissolved gas from the water, and very little water. Water production has never exceeded a few hundred barrels of water per day, in any tests reported. Neither have any tests failed to report some gas.

In analyzing the permeability of the reservoirs in this area, it is difficult to visualize the existence at depth of sands with permeabilities as high as 100 millidarcies. If the permeability of the hypothetical reservoir were only $1.0 \mathrm{md}$, then the flow rate of our geothermal well would be 9,000 bbls of water per day, instead of the 100,000 necessary to make an economic project of the geothermal process.

\section{CONCLUSIONS}

In South Texas geopressured gas reservoirs, the critical parameter is effective permeability. Permeability values have been found to range from less than $0.1 \mathrm{md}$ to $8.0 \mathrm{md}$ in the geopressured gas fields in the study area. Depths of these producing reservoirs lie from $\mathbf{8 , 5 0 0}$ to 14,000 feet.

The possibility of large continuous geopressured aquifers with thickness as great as 500 feet and areal extent of 10 square miles or more is good; the best possibility located so far, is in the McAllen-Pharr-South Edinburg area of south-central Hidalgo County. Here the water salinity is approximately $15,000 \mathrm{ppm} \mathrm{Cl}$, temperatures are above $300^{\circ} \mathrm{F}$ in the zone of interest, and well control is good. However, the effective permeability has been shown to be an inverse function of depth, and at the depths of interest, to average less than $1.0 \mathrm{md}$. This is far too low to provide a useful flow of either geothermal fluid, or of dissolved methane. 


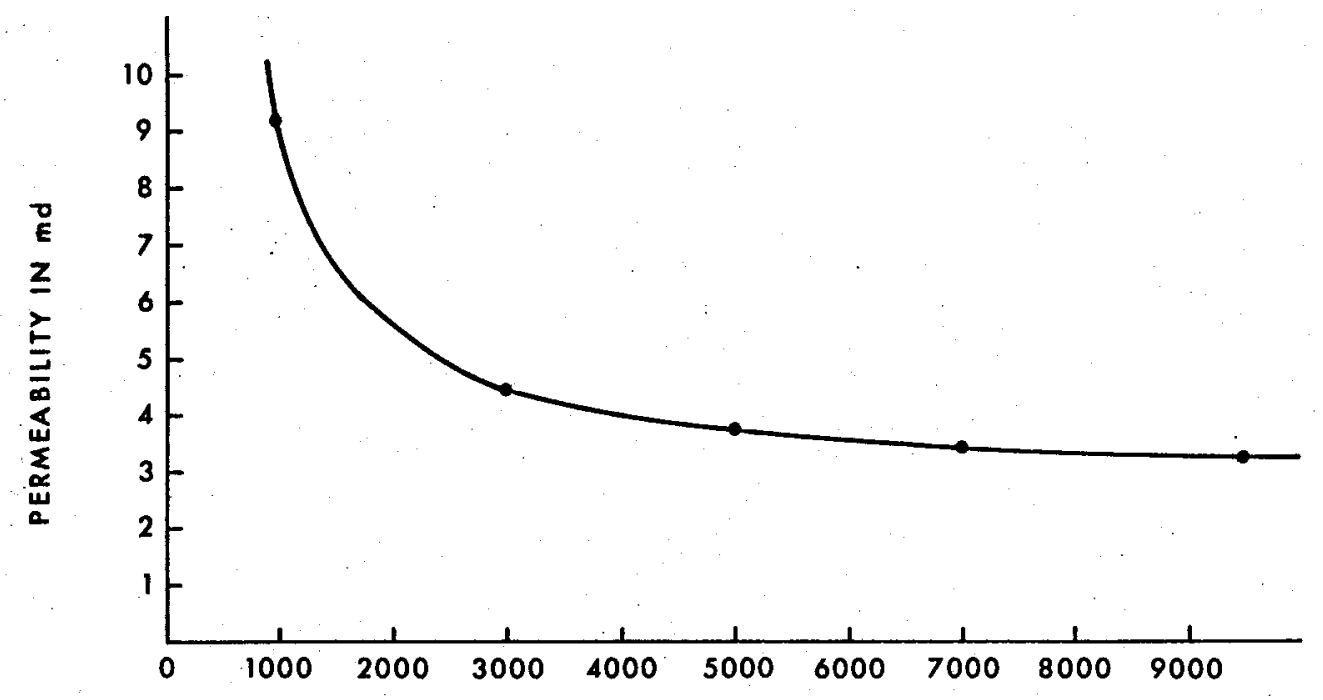

CONFINING PRESSURE IN PSI

FIGURE 14. REDUCTION IN PERMEABILITY AS A FUNCTION OF CONFINING PRESSURE $K_{A I R}=367 \mathrm{md}$

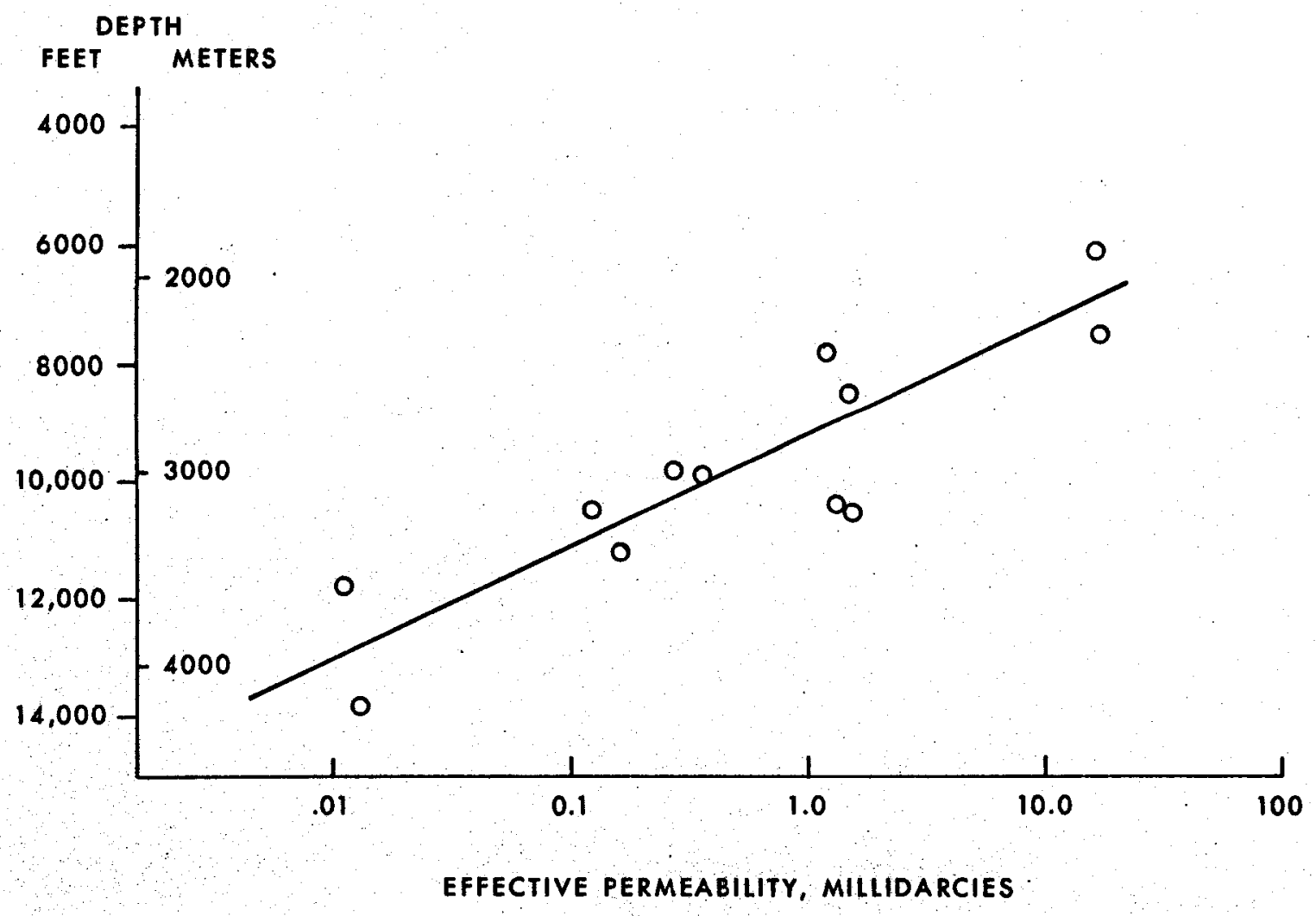

FIGURE 15. VARIATION OF EFFECTIVE PERMEABILITY WITH DEPTH, MCALLEN-PHARR AREA 
TABLE II. MEASURED CORE PERMEABILITY, COMPARED WITH EFFECTIVE PERMEABILITY FROM PRODUCTION TEST, MCALLEN FIELD

\begin{tabular}{|l|c|c|}
\hline \multicolumn{1}{|c|}{ Sand } & $\begin{array}{c}\text { Core } \\
\text { Permeability, } \\
\text { md }\end{array}$ & $\begin{array}{c}\text { Effective } \\
\text { Permeability, } \\
\text { md }\end{array}$ \\
\hline Card & 75 & 17 \\
Biedenharn & 67 & 2.0 \\
8500 & 22 & 1.5 \\
Hansen & 18 & 0.25 \\
Marks & 20 & 1.3 \\
Bond & 18 & 0.2 \\
Kelley & - & 0.03 \\
\hline
\end{tabular}

A number of successful drill stem and production tests have consistently reported gas and water from apparent water sands in wells that were subsequently abandoned. No test has been located which reported water without some gas. On the other hand, both drill stem and production tests have been noted in which no flow of any kind was produced from formations considered of interest to the geothermal study.

This study has extensively investigated Hidalgo County geopressured-production, and the results cast serious doubt on geothermal production possibilities there, based on present reservoir engineering knowledge. There is no production data available for central Cameron and Willacy Counties, since there has been no deep production there.

Tests would be necessary to establish representative permeability values in that area. However, it is likely that low permeability and the entire question of fluid deliverability will be paramount throughout the deep, geopressured horizon, even in the relatively uncemented sediments of Louisiana. The possibility is sufficiently valid to make permeability study a first priority item in further assessment of this resource. 


\section{BIBLIOGRAPHY}

Am. Assn. of Petroleum Geologists, "Geothermal Gradient Maps of the United States," AAI'; (ieothermal Survey Committee, 1971.

Collins, J. W., "The Geology of the McAllen-Pharr Field Area, Hidalgo Co., Tex," Trans. Gulf Coast Assn. Geol. Soc., Volume XVIII, 1968.

White, D. F. and D. L. Williams, (Eds), "Assessment of Geothermal Resources of the United States," Geological Survey Circular 726, USGS, 1975.

Parmigiano, J. M., "Geohydraulic Energy from Geopressured Aquifers," Thesis, Dept. of Petr. Engr., Louisiana State Univ., 1973.

Amyx, Bass \& Whiting, Reservoir Engineering, McGraw Hill, New York, 1960.

Corpus Christi Geol. Soc. Pub., "Typical Oil \& Gas Fields of South Texas," Golden Banner Printing \& Lithography, Corpus Christi, Tex., 1967. 